\title{
Using Antiseptic Mouthrinses to Reduce Sars-Cov2 Oral Viral Load
}

\author{
Michele Benegiamo ${ }^{1}$, Angelo Sammarro ${ }^{2^{\star}}$, Edoardo Rella ${ }^{1}$, Antonio D’Addona ${ }^{3}$, Franklin Garcia-Godoy ${ }^{4,5}$
}

\author{
${ }^{1}$ Department of Head and Neck, Oral Surgery and Implantology Unit, Institute of Clinical Dentistry, Università Cattolica del Sacro Cuore, Fondazione Policlinico \\ Universitario Gemelli, Rome, ITALY \\ ${ }^{2}$ Department of Applied Pharmaceutical Sciences - Quality Control, Università Degli Studi di Firenze, Firenze, ITALY \\ ${ }^{3}$ Professor and Head, Department of Head and Neck, Oral Surgery and Implantology Unit, Institute of Clinical Dentistry, Università Cattolica del Sacro Cuore, Fondazione \\ Policlinico Universitario Gemelli, Rome, ITALY \\ ${ }^{4}$ Professor and Director, Bioscience Research Center, College of Dentistry, University of Tennessee Health Science Center, Memphis, Tennessee, USA \\ ${ }^{5}$ Senior Clinical Investigator, The Forsyth Center, Cambridge, Massachusetts, USA \\ *Corresponding Author: angelo.sammarro@stud.unifi.it
}

Citation: Benegiamo M, Sammarro A, Rella E, D’Addona A, Garcia-Godoy F. Using Antiseptic Mouthrinses to Reduce Sars-Cov2 Oral Viral Load. Electron J Gen Med. 2021;18(1):em273. https://doi.org/10.29333/ejgm/9616

\begin{tabular}{|c|c|}
\hline ARTICLE INFO & ABSTRACT \\
\hline Received: 2 Aug. 2020 & Virucidal activity of Povidone-Iodine (PVP-I) have not yet been performed specifically on SARS-CoV-2. There have \\
\hline Accepted: 20 Sep. 2020 & $\begin{array}{l}\text { been in vitro studies demonstrating its effectiveness against multiple viruses including related coronaviruses. PVP- } \\
\text { I could be effective to reduce viral load from asymptomatic COVID-19 patients and also provide a protective } \\
\text { oropharyngeal hygiene measure for the health professionals. }\end{array}$ \\
\hline
\end{tabular}

Keywords: Coronavirus, COVID-19, oral health, risk management

The Severe Acute Respiratory Syndrome Coronavirus 2 (SARS-CoV-2) is mainly transmitted through droplets, especially in closed and poorly ventilated rooms, or after prolonged, close contact with an infected individual, after considerable exposure to viruses particles; there's the possibility of catching the infection by touching a surface that has been contaminated by SARS-CoV-2, as it can survive for some hours, but the chances are quite low [1-6]. In order to avoid the spread of the infection, all preventive measures and personal protective equipment (PPE) are to be implemented and properly adopted. The standard recommendations to prevent the spread of Coronavirus Disease 2019 (COVID-19) include washing hands with soap and water, or when not possible, using an alcohol-based hand rub; it's also important to cover the nose and the mouth with an elbow or with a disposable tissue when coughing and sneezing; and also to avoid close contact with anyone that has a fever and cough $[7,8]$.

As we have now passed the first peak of the infection, and many social, and productive activities are now returning to the normality, there is a serious risk of an increase of new cases, and therefore, of a new second peak of the infection. In some activities, it is not possible to wear a facemask: for example, when people eat in a restaurant, or practice some sport, or go to the barbershop, to the dentist, or to an ENT specialist. During these activities, viral particles have the ability to become aerosolized after speaking, coughing, or sneezing; these particles can become airborne and can remain in the room for 3 or more hours, and may contaminate multiple surfaces in the surrounding area [9].

While no studies have been conducted on the virucidal activity of Povidone-lodine (PVP-I) on SARS-CoV-2, some in vitro studies have demonstrated its effectiveness against multiple viruses including some related coronaviruses, similar to the SaRS-CoV-2; for example, Eggers et al. observed the effects of a diluted PVP-I (0.23\%) formulation against Severe Acute Respiratory Syndrome Coronavirus 1 (SARS-CoV-1), Middle East Respiratory Syndrome Coronavirus (MERS-CoV), and influenza $\mathrm{A}(\mathrm{A} / \mathrm{H} 1 \mathrm{~N} 1)$; they found, after an application of 15 seconds a $>99.99 \%$ reduction of the viral titers.

Furthermore, many studies have demonstrated that, as oral health can influence systemic diseases, PVP-I can be used to both reduce viral and bacteriological transmission from the oral cavity to other districts and organs, such as the hearth and the liver [10-16].

In the oral cavity and the oropharynx, it has been used safely at a range of doses from $1 \%$ to $10 \%$ [9], and the concentration of PVP-I in commercial, over the counter, oral mouthwashes usually ranges from $7.5 \%$ to $10 \%$.

The authors believe that if one should engage in an activity that cannot be conducted with a face mask, they should also do mouthwash/gargles for 1 minute with a solution of PVP-I diluted 1:3 (for 7.5\% PVP-I) or 1:4 (for 10\% PVP-I), so to achieve a lower than $3 \%$ concentration; this may help reduce the viral load, and the potential aerosolization, of SARS-CoV-2.

This could also provide a protective oropharyngeal hygiene measure for individuals at high risk of exposure such as healthcare professionals.

Author contributions: All authors have sufficiently contributed to the study, and agreed with the results and conclusions.

Funding: No funding source is reported for this study.

Declaration of interest: No conflict of interest is declared by authors. 


\section{REFERENCES}

1. WHO, reference number: WHO/201nCoV/Adjusting_PH_measures/Workplaces/2020 .1.

2. Santacroce L, Charitos IA, Del Prete R. COVID-19 in Italy: An Overview from the First Case to Date. Electron J Gen Med. 2020;17(6):em235. https://doi.org/10.29333/ejgm/7926

3. Santacroce L, Bottalico L, Charitos IA. The Impact of COVID19 on Italy: A Lesson for the Future. Int J Occup Environ Med. 2020;11(3):151-2. https://doi.org/10.34172/ijoem. 2020.1984 PMid:32225178 PMCid:PMC7426732

4. Santacroce L. Letter in response to the article "Enhancing immunity in viral infections, with special emphasis on COVID-19: A review" (Jayawardena et al.). Diabetes Metab Syndr. 2020;14(5):927. https://doi.org/10.1016/j.dsx.2020. 06.009 PMid:32585601 PMCid:PMC7275987

5. Cazzolla AP, Lovero R, Lo Muzio L, Testa NF, Schirinzi AL, Palmieri G, Pozzessere P, Procacci, Di Comite M, Ciavarella D, Pepe MT, De Ruvo C, Crincoli V, Di Serio F, Santacroce L. Taste and smell disorders in COVID-19 patients: role of Interleukin-6. ACS Chem. Neurosci. 2020;11(17):2774-81. https://doi.org/10.1021/acschemneuro.0c00447 PMid:32786309 PMCid:PMC7437448

6. Charitos IA, Ballini A, Bottalico L, Cantore S, Passarelli PC, Inchingolo $F$, et al. Special features of SARS-Cov2 in daily practice. World J Clin Cases 2020;8(18):3920-33. https://doi.org/10.12998/wjcc.v8.i18.3920 PMid:33024749 PMCid:PMC7520789

7. Passarelli PC, Passarelli G, Charitos IA, Rella E, Santacroce L, D'Addona A. COVID-19 and oral diseases: how can we manage hospitalized and quarantined patients while reducing risks? Electron J Gen Med 2020;17(6):em238. https://doi.org/10.29333/ejgm/7945

8. Passarelli PC, Rella E, Manicone PF, Garcia-Godoy F, D'Addona A. The impact of the COVID-19 infection in dentistry. Exp Biol Med (Maywood) 2020;245(11):940-4. https://doi.org/10.1177/1535370220928905 PMid:32436748
9. Passarelli PC, Santacroce L, D'Addona A, Garcia-Godoy F. The Coronavirus Disease-19 Infection and the Oral Mucosa. Open Access Maced J Med Sci, 2020;8(T1):126-8. https://doi.org/10.3889/oamjms.2020.4943

10. Di Serio F, Lovero R, D’Agostino D, Nisi L, Miragliotta G, Contino R, Man A, Ciccone MM, Santacroce L. Evaluation of procalcitonin, Vitamin $\mathrm{D}$ and C-reactive protein levels in septic patients with positive emocoltures. Our preliminary experience. Acta Medica Mediterr 2016;32:1911-1914.

11. Azzolino D, Passarelli PC, De Angelis P, Piccirillo GB, D'Addona A, Cesari M. Poor oral health as a determinant of malnutrition and sarco- penia. Nutrients 2019;11:2898. https://doi.org/10.3390/nu11122898 PMid:31795351 PMCid:PMC6950386

12. Bollero P, Passarelli PC, D’Addona A, Pasquantonio G, Mancini M, Condo ` R, Cerroni L. Oral management of adult patients undergoing hematopoietic stem cell transplantation. Eur Rev Med Pharmacol Sci 2018;22:87687.

13. Passarelli PC, Lopez MA, Mastandrea Bonaviri GN, GarciaGodoy F, D'Addona A. Taste and smell as chemosensory dysfunctions in COVID-19 infection. Am J Dent 2020;33(3):135-7.

14. Passarelli PC, De Leonardis M, Piccirillo GB, et al. The Effectiveness of Chlorhexidine and Air Polishing System in the Treatment of Candida albicans Infected Dental Implants: An Experimental In Vitro Study. Antibiotics (Basel) 2020;9(4):179. https://doi.org/10.3390/ antibiotics9040179 PMid:32295150 PMCid:PMC7235741

15. Passarelli PC, Pagnoni S, Piccirillo GB, et al. Reasons for Tooth Extractions and Related Risk Factors in Adult Patients: A Cohort Study. Int J Environ Res Public Health 2020;17(7):2575. https://doi.org/10.3390/ijerph17072575 PMid:32283707 PMCid:PMC7178127

16. Passarelli PC, Pasquantonio G, D’Addona A. Management of Surgical Third Lower Molar Extraction and Postoperative Progress in Patients With Factor VII Deficiency: A Clinical Protocol and Focus on This Rare Pathologic Entity. J Oral Maxillofac Surg 2017;75(10):2070.e1-2070.e4. https://doi.org/10.1016/j.joms.2017.06.010 PMid:28672139 